\title{
Chemical composition of essential oils from Pinus caribaea Morelet needles
}

\author{
John Mary Kirima ${ }^{\mathrm{a}}$, Moses Okuta ${ }^{\mathrm{a}}$, Timothy Omara ${ }^{\mathrm{b}, \mathrm{c}, \mathrm{d}^{*}}$ \\ ${ }^{a}$ Department of Chemistry, Faculty of Science, Kyambogo University, P. O. Box 1, Kyambogo, \\ Kampala, Uganda. \\ ${ }^{b}$ Department of Chemistry and Biochemistry, School of Sciences and Aerospace Studies, Moi \\ University, Uasin Gishu County, P. O. Box 3900-30100, Academic Highway, Eldoret, Kenya. \\ ${ }^{c}$ Department of Quality Control and Quality Assurance, Product Development Directory, \\ AgroWays Uganda Limited, Plot 34-60, Kyabazinga Highway, P. O. Box 1924, Jinja, Uganda. \\ ${ }^{d}$ Africa Centre of Excellence II in Phytochemicals, Textiles and Renewable Energy (ACE II PTRE), \\ Moi University, Uasin Gishu County, P. O. Box 3900-30100, Academic Highway, Eldoret, Kenya. \\ prof.timo2018@gmail.com,prof.timo2018@mu.ac.ke
}

Keywords: Allelochemicals, Buikwe district, limonene.

Plant allelochemicals from essential oils have recently received considerable attention in pharmaceutical, cosmetic and agricultural sectors due to their biodegradability and low toxicity. This study analyzed the composition of essential oils of Pinus caribaea Morelet var. hondurensis needles. Thirty-nine compounds were identified using gas chromatography/mass chromatography and gas chromatography, and the most abundant components were limonene (38.6\%), $\alpha$-pinene (27.6\%), borneol (6.7\%) and myrcene (3.5\%). Aristolene, ledol and guaiol were reported for the first time in $P$. caribeae needles. Composition of the needles was dominated by monoterpene hydrocarbons $(77.2 \%)$ followed by oxygenated monoterpenes $(12.0 \%)$, sesquiterpene hydrocarbons $(4.7 \%)$ and oxygenated sesquiterpenes $(1.7 \%)$.

\section{Introduction}

There has been renewed interest in utilization of allelochemicals and signaling compounds from aromatic plants for various purposes due to their desirable biological and medicinal properties [1]. In plants, these chemicals are produced as secondary metabolites. Allelochemicals, for example, participate in defense of plants against microbial attack, competition with other plants (allelopathy) as well as guard against predation by herbivores [2]. Essential oils is the broad group where these chemicals are derived from and have been a subject of obsessive research over the past decades.

In continuity of our studies on identification and characterization of bioactive compounds in medicinal plants utilized in East Africa [3-5], we characterized the phytochemicals in essential oils of Pinus caribaea needles from Uganda. Pinus 
caribaea Morelet is a resinous tree with evergreen needles and grows up to $30 \mathrm{~m}$. On the phytochemistry of its needle oils, there are a few reports from other countries outside East Africa [6-10].

\section{Experimental part}

Fresh P. caribaea needles $(3 \mathrm{~kg})$ were collected from Ferdsult Pine Forest, Luwombo village, Buikwe district of Uganda from identified cultivated plants. Needles were collected from various parts of the crowns to overcome plant plasticity phenomena $[11,12]$. They were identified as $P$. caribaea Morelet var. hondurensis by a botanist at Makerere University Herbarium where a voucher sample (No. JM001) was deposited.

Aliquots $(500 \mathrm{~g})$ of crushed needles were hydrodistilled using a modified Clevenger-type apparatus for $3 \mathrm{hrs}$. The oil was dried using anhydrous sodium sulfate and stored in amber bottles away from UV light at $4{ }^{\circ} \mathrm{C}$.

Gas chromatography/mass spectrometry analysis was carried out with an Agilent 5975 GC/MSD system. One $\mathrm{mL}$ of the oil was withdrawn by an auto-sampling system. Innowax FSC column (60 $\mathrm{m} \times 0.25 \mathrm{~mm}, 0.25 \mathrm{~mm}$ ) was used with helium as the carrier gas $(0.8 \mathrm{~mL} / \mathrm{min})$. GC oven temperature was kept at $60^{\circ} \mathrm{C}$ for 10 minutes, programmed to $220^{\circ} \mathrm{C}$ at a rate of $4^{\circ} \mathrm{C} / \mathrm{min}$, kept constant at $220^{\circ} \mathrm{C}$ for 10 minutes, and then programmed to $240^{\circ} \mathrm{C}$ at a rate of $1^{\circ} \mathrm{C} / \mathrm{min}$. Split ratio was adjusted at 40:1. The injector temperature was set to $250^{\circ} \mathrm{C}$. Mass spectra were recorded at $70 \mathrm{eV}$. GC analysis was carried out using an Agilent 6890N GC system. The flame ionization detector temperature was set at $300^{\circ} \mathrm{C}$. To obtain the same elution order with GC/MS, simultaneous autoinjection was done on a duplicate of the same column applying the same conditions described before. Relative percentage amounts of the separated compounds were calculated from FID chromatograms.

Constituents were identified by comparison of their retention indices with those reported in literature [7, 13-20]. Matching against libraries such as Adams Library and those of reference compounds from NIST database were done.

All extraction and analysis of essential oils were done in triplicate.

\section{Results and discussion}

The essential oil was a pale-yellow liquid with a strong aroma. The mean yield of the oils was $0.33 \%(\mathrm{v} / \mathrm{w})$. This is comparable to $0.02-1.0 \%$ reported for fresh needles of $P$. caribaea elsewhere [6-8]. A total of 39 compounds were identified and quantified, representing $95.6 \%$ of the oils (Table 1). Structures of the most abundant components are shown in Figure 1.

The Pinus genus has been previously studied and the presence of essential oils, tannins, flavonoids and alkaloids reported [21, 22]. Analysis of the essential oils of $P$. caribaea needles in this study 
identified 39 compounds. Aristolene, ledol and guaiol were reported for the first time in $P$. caribeae needles.

Table 1. Phytochemicals identified in P. caribaea fresh needle oils from Uganda

\begin{tabular}{|l|l|l|l|}
\hline Peak & Constituent & $\mathrm{RI}^{\mathrm{a}}$ & Peak area (\%) \\
\hline $\mathbf{1}$ & $\boldsymbol{\alpha}$-Pinene & $\mathbf{1 0 3 2}$ & $\mathbf{2 7 . 6 \pm \mathbf { 0 . 2 }}$ \\
\hline 2 & $\alpha$-Thujene & 1035 & 0.7 \\
\hline 3 & Camphene & 1076 & $1.6 \pm 0.2$ \\
\hline 4 & Hexanal & 1093 & Trace \\
\hline 5 & $\beta$-Pinene & 1118 & $0.6 \pm 0.1$ \\
\hline 6 & Sabinene & 1132 & 0.9 \\
\hline $\mathbf{7}$ & Myrcene & $\mathbf{1 1 7 4}$ & $\mathbf{3 . 5} \pm \mathbf{0 . 2}$ \\
\hline & $\alpha$-Phen & $\mathbf{2 . 1} \pm 0.2$ \\
\hline
\end{tabular}

Figure 1. Structure of the major compounds identified in P. caribaea needle oils: (a) Limonene, (b) $\alpha$-Pinene, (c) Borneol, and (d) Myrcene.

The major components of the oils were limonene $(38.6 \%), \alpha$-pinene $(27.6 \%)$, borneol $(6.7 \%)$ and myrcene (3.5\%). Chowdhury et al. [8] reported similar results in which limonene was not detected in essential oils of $P$. caribaea resins but was the dominant component in the fresh needles (48.84\%), dried needles (31.58\%) and inflorescence (32.14\%) followed by caryophyllene $(23.82 \%$ and $14.45 \%)$, germacrene D $(8.40 \%$ and $2.59 \%)$ in fresh and dried needles respectively. In an earlier study in Nigeria [6], the major constituents of essential oils from $P$. caribaea air-dried needles were $\beta$ phellandrene (67.9\%), $\beta$-caryophyllene (10.2\%) and $\alpha$-pinene (5.4\%). In another investigation, it was reported that the major components of oils from fresh needles of $P$. caribaea in Nigeria were limonene (42\%), $\beta$-phellandrene (24.4\%) and $\beta$ caryophyllene (7.6\%) [7]. The differences in the

Trace $=<0.01 \% .{ }^{\mathrm{a}} \mathrm{RI}=$ Retention index as determined on an Innowax FSC column. Peak area presented as mean \pm standard deviation of triplicates.

chemical composition of the essential oils recorded in this study and those reported by 
preceding authors could be because the climatic conditions and soil properties of Uganda (East Africa) is different from that of Bangladesh (South Asia) and Nigeria (West Africa). Previous studies support that the chemical composition of essential oils and oleoresins of pines exhibit qualitative and quantitative variations both between and within the same species $[7,10,22-$ $30]$.

As reported for essential oils from other Pinus species [24, 30-32], the chemical composition of $P$. caribaea needles in this study was dominated by monoterpene hydrocarbons $(77.2 \%)$ followed by oxygenated monoterpenes (12.0\%), sesquiterpene hydrocarbons (4.7\%) and then oxygenated sesquiterpenes $(1.7 \%)$. The major constituents of the monoterpene hydrocarbons were limonene (38.6\%), $\alpha$-pinene (27.6\%), myrcene (3.5\%) and $\alpha$-phellandrene (2.1\%). Sesquiterpene hydrocarbons was dominated by $\beta$-caryophyllene $(1.2 \%)$, aristolene $(0.9 \%)$ and germacrene D $(0.8 \%)$. The dominant monoterpene hydrocarbon constituents in our study differed from those reported by Coppen et al. [23, 33, 34], Ekundayo [30], Dagne et al. [35], and Barnola and Cedeño [9] for the same species in which $\alpha$-pinene (63.2-87.1\%) was the major constituent. The abundance of monoterpenes in the essential oils of $P$. caribaea seems to be in congruence with published reports where limonene and $\beta$-phellandrene dominated $[10,36]$ and $\beta$-phellandrene occurred in nonquantitatively larger amounts [36]. However, $\beta$ - myrcene, sabinene and other monoterpenoids that were prominent compounds in previous reports $[9,10,36]$ were detected in lower quantities in this study, corroborating a recent observation [7]. Similarly, $\alpha$-ocimene was not identified as one of the components, which is in good agreement with previous reports $[10,36]$.

Such differences in the chemical composition of the essential oils may be attributed to factors such as part of the plant used, time of collection, plant disease, genetic factors (chemotype), soil and climatic conditions, and age of the plant $[6,7,9$ 12, 34, 36, 37]. For example, a study on $P$. caribaea (var. caribaea, var. bahamensis and var. hondurensis) xylem resins in different provenances of Zimbabwe [34] reported that $\alpha$ pinene (20.8-66.6\%) and $\beta$-phellandrene (19.4$59.9 \%$ ) predominated and jointly accounted for $80-90 \%$ of the total monoterpene hydrocarbons. Barnola et al. [37] reported that seasonal changes between dry and rainy seasons may be associated with the caryophyllene content variation (in conjunction with that of $\alpha$-pinene) in Pinus caribaea needles.

Considering the nature of the compounds identified, essential oils of $P$. caribaea needles could be used in food, pharmaceutical and cosmetic industries. Monoterpenes such as limonene, $\alpha$-pinene, camphene and $\alpha$-terpinene have been reported to have contact and fumigant toxicity against stored product pests [38, 39]. Limonene, the main component of the essential 
oils has been previously reported to possess good repellent and toxic properties against several arthropods [40-42] and it is an ingredient of more than 15 insecticide products [43]. On the other hand, limonene and $\beta$-phellandrene are important constituents of fragrances, and are used as flavoring agents in food manufacturing as well as cosmetic industries [44, 45]. Essential oils of $P$. caribaea needles rich in $\beta$-phellandrene was reported to possess antibacterial activity against Pseudomonas aeruginosa [7].

\section{Conclusion}

The composition of essential oils of $P$. caribaea fresh needles grown in Buikwe district of Uganda is dominated by monoterpenes followed by oxygenated monoterpenes, sesquiterpenes and oxygenated sesquiterpenes. The current study, in part, supports the traditional use of $P$. caribaea needles as bioinsecticides for traditional management of maize and bean weevils in Uganda.

\section{Acknowledgements}

The authors are grateful to the Government of the Republic of Uganda for the scholarship awarded to JMK that led to this communication. The analytical support of Department of Chemistry, Kyambogo University is acknowledged.

\section{References}

[1] Lucia A, Toloza AC, Guzmán E, Ortega F, Rubio RG. Novel polymeric micelles for insect pest control: encapsulation of essential oil monoterpenes inside a triblock copolymer shell for head lice control. PeerJ. 2017; 5: e3171.

[2] Kong C-H, Xuan TD, Khanh TD, Tran H-D, Trung NT. Allelochemicals and signaling chemicals in plants. Molecules. 2019; 24: 2737.

[3] Omara T, Kateeba KF, Musau B, Kigenyi E, Adupa E, Kagoya S. Bioinsecticidal activity of eucalyptol and 1R-alpha-pinene rich acetonic oils of Eucalyptus saligna on Sitophilus zeamais Motschulsky, 1855 (Coleoptera: Curculionidae). J Health Environ Res. 2018;4:153-160.

[4] Omara T, Kagoya S, Openy A, Omute T, Ssebulime S, Kiplagat KM, et al. Antivenin plants used for treatment of snakebites in Uganda: ethnobotanical reports and pharmacological evidences. Trop Med Health. 2020; 48: 6 .

[5] Omara T, Kiprop AK, Ramkat RC, Cherutoi J, Kagoya S, Nyangena DM, et al. Medicinal plants used in traditional management of cancer in Uganda: A review of ethnobotanical surveys, phytochemistry, and anticancer studies. Evid Based Complement Altern Med. 2020; 1-26. doi: $10.1155 / 2020 / 3529081$.

[6] Sonibare OO, Olakunle K. Chemical composition and antibacterial activity of the essential oil of Pinus caribaea from Nigeria. Afr J Biotechnol. 2008;7: 24622464.

[7] Moronkola DO, Ogunwande IA, Oyewole IO, H. CBK, Ozek T, Ozek G. The needle oil of Pinus caribaea Morelet from Nigeria. J Essent Oil Res. 2009; 21: 342-344. [8] Chowdhury JU, Bhuiyan MNI, Nandi NC. Essential oil constituents of needles, dry needles, inflorescences and resins of Pinus caribaea Morelet growing in Bangladesh. Bangladesh J Bot. 2008; 37:211212.

[9] Barnola LF, Cedeño A. Inter-population differences in the essential oils of Pinus caribaea needles. Biochem System Ecol. 2000; 28: 923-931.

[10] Barnola LF, Cedeño A, Hasegawa M. Intraindividual Variations of volatile terpene contents in Pinus caribaea needles and its possible relationship to Atta 
laevigata herbivory. Biochem System Ecol. 1997; 25 :707716.

[11] Roussis V, Petrakis PV, Ortiz A, Mazomenos BE. Volatile constituents of needles of five Pinus species grown in Greece. Phytochem. 1995; 39: 357-361.

[12] Bradshaw AD. Evolutionary significance of phenotypic plasticity in plants. Adv Genet. 1965; 13: 115155.

[13] Demirci B, Yusufoglu HS, Tabanca N, Temel HE, Bernier UR, Agramonte NM, et al. Rhanterium epapposum Oliv. essential oil: chemical composition and antimicrobial, insect-repellent and anticholinesterase activities. Saudi Pharm J. 2017; 25:703-708.

[14] Saglam H, Gozler T, Kivcak B, Demirci B, Baser KHC. Volatile compounds from Haplophyllum myrtifolium. Chem Nat Compd. 2001; 37: 442-424.

[15] Akın MH, Saraçoğlu T, Demirci B, Başer KHC, Küçüködük M. Chemical composition and antibacterial activity of essential oils from different parts of Bupleurum rotundifolium L. Rec Nat Prod. 2012; 6: 316-320.

[16] Baser KHC, Demirci B, Kurkcuoglu M, Satin F, Tumen G. Comparative morphological and phytochemical charactertization of Salvia cadmica and S. smyrnaea. Pak J Bot. 2009;41 :1545-1555.

[17] Baser KHC, Demirei B, Özek T, Akalin E, Özhatay N. Micro-distilled volatile compounds from Ferulago species growing in Western Turkey. Pharm Biol. 2002; 40: 466-471.

[18] Tabanca N, Demirci F, Ozek T, Tumen G, Baser KHC. Composition and antimicrobial activity of the essential oil of Origanum $\mathrm{x}$ dolichosiphon P. H. Davis. Chem Nat Compd. 2001; 37: 238-241.

[19] Baser KHC, Nuriddinov HR, Ozek T, Demirci AB, Azcan N, Nigmatullaev AM. Essential oil of Arischrada korolkowii from the Chatkal mountains of Uzbekistan. Chem Nat Compd. 2002;38: 51-53.

[20] Kaya A, Benirci B, Baser KHC. Micromorphology of glandular trichomes of Nepeta congesta Fisch. Mey. var. congesta (Lamiaceae) and

chemical analysis of the essential oils. South Afr J Bot. 2007;73 : 29-34.

[21] Fuentes JL, Vernhe M, Cuetara EB, SánchezLamar A, Santana JL, Llagostera M. Tannins from barks of Pinus caribaea protect Escherichia coli cells against DNA damage induced by gamma-rays. Fitoterapia. 2006; 77:116-120.

[22] Hmamouchi M, Hmamouchi J, Zouhdi M. Chemical and antimicrobial properties of essential oils of five Moroccan Pinaceae. J Essent Oil Res. 2001;13: 298302 .

[23] Coppen JJW, James DJ, Robinson JM, Subansenee W. Variability in xylem resin composition amongst natural populations of Thai and Filipino Pinus merkusii de Vriese. Flav Fragr J. 1998; 13: 33-39.

[24] Macchioni F, Cioni PL, Flamini G, Morelli I, Maccioni S, Ansaldi M. Chemical composition of essential oils from needles, branches and cones of Pinus pinea, P. halepensis, P. pinaster and P. nigra from central Italy. Flavour Fragr J. 2003; 18: 139-143.

[25] Jantan B. A comparative study of the oleoresins of three Pinus species from Malaysian pine plantations. J Essent Oil Res. 2002; 14:327-332.

[26] Venskutonis PR, Vyskupaityte K, Plausinaitis R. Composition of essential oils of Pinus sylvestris L. from different locations of Lithuania. J Essent Oil Res. 2000;12: 559-565.

[27] Pagula FP, Baeckström PP. Studies on essential oil-bearing plants from Mozambique: Part II. Volatile leaf oil of needles of Pinus elliottii Engelm. and Pinus taeda L. J Essent Oil Res. 2006;18:32-34.

[28] Ghosn MW, Saliba NA, Talhouk SY. Chemical composition of the needle-twig oils of Pinus brutia Ten. J Essent Oil Res. 2006;18: 445-447.

[29] Dob T, Berramdane T, Chelghoum C. Essential oil composition of Pinus halepensis Mill. from three different regions of Algeria. J Essent Oil Res. 2007;19: 4043. 
[30] Ekundayo O. Monoterpenes composition of the needles oils of Pinus species. J Chromatogr Sci. 1978;16:294-295.

[31] Ekundayo O. Volatile constituents of Pinus needle oils. Flavour Fragr. 1988; $3: 1-11$.

[32] Stevanoic TF, Garneau F, Jean FI, Gagnon H, Vilotic D, Petrovic S, et al. The essential oil composition of Pinus mugo Terra from Serbia. Flavour Fragr. 2004; 20 : 96-97.

[33] Coppen JJW, Gay C, James DJ, Robinson JM, Mullin IJ. Xylem resin composition and chemotaxonomy of three varieties of Pinus caribaea. Phytochem. 1993; 33: 1103-1111.

[34] Coppen JJW, Ronbinson JM, Mullin IJ. Composition of xylem resin from five Mexican and Central American Pinus species growing in Zimbabwe. Phytochem. 1988; 27: 1731-1734.

[35] Dagne E, Bekele T, Bisrat D, Alemayehu M, Warka T, Elokaokich JP. Essentail oils of resins from three Pinus species growing in Ethiopia and Uganda. Ethiopia $\mathbf{J}$ Sci. 1999; 22: 253-257.

[36] Valterová I, Sjödin K, Vrkoc J, Norin T. Contents and enantiomeric compositions of monoterpene hydrocarbons in xylem oleoresins from four Pinus species growing in Cuba. Comparison of trees unattacked and attacked by Dioryctria horneana. Biochem System Ecol. 1995; 23:1-15.

[37] Barnola LF, Hasegawa M, Cedefm A. Mono- and sesquiterpene variation in Pinus caribaea needles and its relationship to Atta laevigata herbivory. Biochem System Ecol. 1994; 22: 437-445.

[38] Papachristos DP, Karamanoli KI, Stamopoulos DC, Spiroudi UM. The relationship between the chemical composition of three essential oils and their insecticidal activity against Acanthoscelides obtectus (Say). Pest Manage Sci. 2004; 60: 514-520.

[39] Stamopoulos DC, Damos P, Karagianidou G. 2007. Bioactivity of five monoterpenoid vapours to Tribolium confusum (du Val) (Coleoptera: Tenebrionidae). J Stored Prod Res. 2007; 43: 571-577.
[40] Showler AT, Harlien JL, Perez de Léon AA. Effects of laboratory grade limonene and a commercial limonene-based insecticide on Haematobia irritans irritans (Muscidae: Diptera): deterrence, mortality, and reproduction. J Med Entomol. 2019; 56: 1064-1070.

[41] Mursiti S, Estari NAL, da Febriana Z, Rosanti Y, Ningsih TW. The activity of d-Limonene from sweet orange peel (Citrus sinensis L.) extract as a natural insecticide controller of bedbugs (Cimex cimicidae). Orient J Chem. 2019; 35: 1420-1425.

[42] Guo S, Zhang W, Liang J, You C, Geng Z, Wang $\mathrm{C}, \mathrm{Du}$ S. Contact and repellent activities of the essential oil from Juniperus formosana against two stored product pests. Molecules. 2016; 21: 504.

[43] Hebeish A, Fouda MMG, Hamdy IA, El-Sawy SM, Abdel-Mohdy FA. Preparation of durable insect repellent cotton fabric: limonene as insecticide. Carbohydr Polym. 2008; 74: 268-273.

[44] Bakkali F, Averbeck S, Averbeck D, Idaomar M. Biological effects of essential oils-a review. Food Chem Toxicol. 2008; 46: 446-475.

[45] Karl-Georg F, Franz-Josef H, Johannes P, Wilhelm P, Dietmar S, Kurt B, Dorothea G, Horst S. Flavors and Fragrances. Ullmann's Encyclopedia of Industrial Chemistry. 2003. 